\title{
Exploring the role of values and norms towards consumers' intentions to patronize retail apparel brands engaged in corporate social responsibility (CSR)
}

\author{
Sonali Diddi ${ }^{*}$ and Linda S. Niehm²
}

*Correspondence:

sonali.diddi@colostate.edu

${ }^{1}$ Department of Design and Merchandising, College

of Health and Human

Sciences, Colorado State

University, Fort Collins, CO

80523, USA

Full list of author information

is available at the end of the

article

\begin{abstract}
This study provides understanding of factors that affect US consumers' intentions to patronize retail apparel brands engaged in corporate social responsibility (CSR). The study utilizes a dual theoretical framework comprised of the theory of reasoned action (TRA) and Schwartz's value theory. Data were collected via a web-based survey from a national sample of 407 US consumers. Findings revealed that moral norms, subjective norms, and attitudes were all important predictors of US consumers' intentions to patronize retail apparel brands engaged in CSR. Overall, the results of this study provide important theoretical implications for extending the TRA to include measures of selftranscendent values (universalism and benevolence) and moral norms in the context of consumers' ethical decision making. The findings also provide important practical implications for retail apparel brands planning to incorporate CSR policies in their corporate agenda. It is proposed that retail apparel brands should integrate CSR related information in their strategic marketing activities to increase consumer awareness of its socially responsible business practices, which in turn may enhance brand image.
\end{abstract}

Keywords: Corporate social responsibility, Values, Norms

\section{Introduction}

Current global patterns of economic development have created numerous social and environmental challenges. The origin and growth of these global problems are largely anthropogenic - that is, primarily due to human activities (Laudal 2010). These problems are also affected by decision-making processes at different stakeholder levels: individual, political, organizational, and societal. Individual consumption decisions and their antecedents have been extensively addressed in past consumer behavior research. The present study addresses factors that affect US consumers' intentions to patronize retail apparel brands engaged in corporate social responsibility (CSR).

Industries play a vital role in the development of contemporary society and, therefore, bear a significant responsibility for its well-being. For this reason, sustainable business practices have emerged as an important element of corporate strategy (Moosemayer and Fuljahn 2010), commonly referred to as CSR. The practice of companies addressing and

(C) The Author(s) 2017. This article is distributed under the terms of the Creative Commons Attribution 4.0 International License (http://creativecommons.org/licenses/by/4.0/), which permits unrestricted use, distribution, and reproduction in any medium, provided you give appropriate credit to the original author(s) and the source, provide a link to the Creative Commons license, and indicate if changes were made. 
reporting sustainability-related issues has grown steadily over the past several decades. According to a KPMG survey (2015) of corporate sustainability reporting, $90 \%$ of the Global Fortune 250 (G250) and 75\% of the 100 world's largest companies by revenue (N100) currently report corporate responsibility using global reporting initiative (GRI) standards.

From a consumer perspective, concerns regarding the environmental and social impacts of companies' actions are also increasing. According to a 2012 survey of 4000 managers and executives worldwide (Knut et al. 2012), 70\% of firms have placed sustainability on their management agenda. Interestingly, $41 \%$ of the survey respondents cited consumer preferences as the most common reason for providing sustainable products and services (Simmons and Becker-Olsen 2006). Research pertaining to CSR and its influence on consumer purchase decisions has been conducted in numerous industry sectors and distribution channels including organic food, health, energy, and water (Dodd and Supa 2011; Arvola et al. 2008; Godin et al. 2005). A growing stream of research has also investigated sustainable apparel consumption (Dickson 2000; Kang and Hustvedt 2014a, b; Kozar and Connell 2013) with a focus on consumers' environmental concern, knowledge, attitudes and behaviors.

The retail apparel industry is particularly impacted by the issue of sustainability, as the global apparel supply chain contributes significantly to pollution and ecological hazards (Peterson et al. 2012). Globalization has also contributed to the (un)sustainability of the retail apparel industry. Additionally, poverty prevalent in developing and under-developed countries, contributes towards the availability of cheap labor leading to exploitation of the workforce. Apparel companies increasingly outsource production to take advantage of such cheap labor in these countries, where people are willing to work in sweatshop conditions. Furthermore, women in developing countries are more vulnerable to working in poor conditions because there are few other legitimate opportunities for them to earn income (Laudal 2010). Also, lax regulations in many developing countries mean that chemical wastes need not be disposed of in an environmentally friendly way (Laudal 2010). As apparel is manufactured in response to consumer demand, it follows that growing apparel consumption contributes to increased pollution, shortages of clean water, and depletion of fossil fuels and raw materials (Chan and Wong 2012).

Consumers are increasingly taking into account retail brands' CSR practices when making purchase decisions. Previous research in other domains (e.g. Arvola et al. 2008; Brown and Dacin 1997; Poortinga et al. 2004) has shown that consumers value CSR and feel good when they buy from brands associated with socially responsible behaviors. Scholarly research pertaining to CSR in the retail apparel sector has focused primarily on topics related to social issues (e.g. sweatshops, fair trade, social responsibility labelling) prevalent in apparel companies (Dickson 2000; Dickson and Eckman 2006; Hustvedt et al. 2008; Kozar and Connell 2010); marketing and promotion (Hyllegard et al. 2012; Kim et al. 2012; Phau and Ong 2007) and environmental impacts of textiles and apparel production (Brosdahl and Carpenter 2010; Hustvedt and Bernard 2010). A limited number of studies have focused on CSR in the apparel industry from management and supply chain perspectives (de Abreu et al. 2012; Dargusch and Ward 2010; Laudal 2010); transparency and social responsibility (Kang and Hustvedt 2014a, b; Bhaduri and Ha-Brookshire 2011). Further, the findings of consumer behavior studies focusing 
on apparel and textiles and social responsibility are often contradictory. For instance, scholars including Dickson (2000), Kang and Hustvedt (2014a, b), Kozar and Connell (2013), among others, have found an attitude-behavior-gap that often exists in consumers' knowledge and attitudes of social and environmental sustainability and apparel purchasing intentions.

To date, minimal research has investigated the influence exerted by individual's values and moral norms on consumers' attitudes and intentions to patronize retail apparel brands' engaged in CSR practices. The lack of research in these areas warrants further investigation to determine the behavorial antecedents of consumer intentions to patronize retail apparel brands engaged in CSR activities. The objective of the present study was to understand the role of consumers' personal normative influence (values and norms) on their attitudes and patronage intentions of retail apparel brands engaged in CSR. Specifically, this study builds on research by Conner and Armitage (1998) and Ferrell et al. (2013), to include values and norms in behavioral theories to better understand consumers' ethical decision making. An ethical decision making model encompassing consumers' personal normative influences was proposed and empirically tested (see Fig. 1). This study is also among the first to test the relationship between Schwartz's selftranscendent values (universalism and benevolent), moral norms, and elements of the TRA, providing a unique theoretical perspective concerning consumers' ethical decision making in the retail apparel context.

\section{Literature review}

\section{Theoretical background}

A dual theoretical framework comprised of the theory of reasoned action (TRA) and Schwartz's value theory was employed for this study. This framework facilitated examination of consumer attitudes, their antecedents, and the influence of each on consumers' intentions to patronize retail apparel brands engaged in CSR. In addition, this study explored the role of personal values and moral norms in consumers' ethical decisionmaking, specifically in an apparel purchasing context.

\section{Theory of reasoned action (TRA)}

TRA has been extensively used in consumer behavior studies (Ajzen 1991). The TRA focuses on theoretical constructs concerned with factors that determine the likelihood

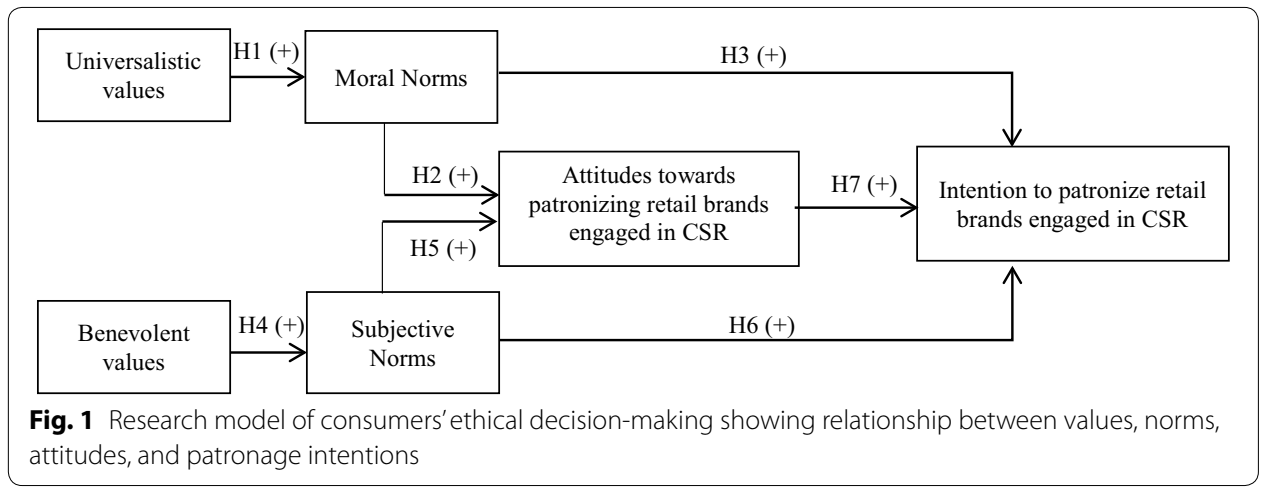


of performing a specific behavior. An individual's intention to engage in a specific behavior is a function of his/her attitude and subjective norms. Behavioral beliefs act as underlying influence on individual's attitude and normative beliefs influence the subjective norms which in turn towards performing a behavior and. Attitudes towards a behavior is based on individuals evaluation of performing the behavior. The TRA takes into account only behaviors that are under an individual's volitional control (Ajzen 1991). Some studies have used the TRA in an apparel purchasing context (Kozar and Marcketti 2011; Summers et al. 2006; Yan et al. 2010). Kozar and Marcketti (2011) explored the influence of ethical and materialism values as antecedents to young consumers' intentions to purchase counterfeit apparel products. Summers et al. (2006) found that attitude towards performing the behavior, subjective norm, social acceptance, and fashion involvement were significant predictors of consumers' purchase intention of luxury alligator leather products. Yan et al's (2010) study also found that attitude toward brand, subjective norm, attitude toward advertisement, eco-fashion involvement, and environmental commitment were strong predictors of intention to purchase an environmentally friendly apparel brand. Studies using TRA in apparel purchasing context have primarily focused on subjective norms, attributing much less importance to personal moral norms (i.e. an individual's belief or perception about what is right or wrong). To address the gap in research, the present study proposes an extension of the TRA to include a measure of moral norms based on personal values as antecedents to attitude and purchase intentions. Justification for the addition of this construct is based on its central role in a number of ethical frameworks (Hunt and Vitell 1986; Rest 1983).

\section{Schwartz value theory}

Schwartz's (1992) theory differentiates between different value types and posits that values are a continuum of shared motivational emphases. The different values identified by Schwartz (1992) are broadly organized in two dimensions underlying four broad higherorder values, based on their motivational similarities and dissimilarities. One dimension contrasts openness to change (self-direction, stimulation, hedonism) and conservation values (conformity, tradition, security). The other dimension contrasts self-enhancement and self transcendence values. Self-transcendent values (universalism and benevolence) emphasize equality and concern of others welfare whereas, self-enhancement values (power and achievement) focus on individual's own success and domination over others. This study explored the role of self-transcendence values as they are especially relevant to consumers' ethical decision-making processes. The self-transcendence dimension encompasses values that "motivate people to transcend selfish concerns and promote the welfare of others, close and distant, and of nature" (Schwartz 1992, pp. 43-44). The self-transcendence dimension includes both universalistic and benevolent values.

\section{Corporate social responsibility (CSR)}

This study utilized the International Organization for Standardization's (ISO) definition of CSR as it is adopted by most of Fortune 500 companies. According to the ISO 26000:2010, CSR is defined as an organization's responsibility for their decisions and actions that can impact society and the environment. Their new standard, ISO 26000:2010, audits a firm's socially responsible performance (ISO, n.d.) on various 
parameters like human rights, labor practices, social performance, environmental footprint, product responsibility and economic viability.

Previous research has shown a positive relationship between a company's CSR activities and consumers' attitudes towards that company and its products (Lee and Shin 2010; Lii and Lee 2012). Consumers are increasingly taking into account company's CSR record in their decisions to purchase their products (Marin et al. 2009; Groza et al. 2011). According to a Global CSR study conducted by a leading market research company (Cone Inc. 2013), one in three consumers feel businesses should address social and environmental needs in their business operations.

The retail apparel industry has received immense media attention with regard to issues of fair treatment of workers, use of sweatshop labor, poor working conditions and ethical decisions about buying or sourcing raw materials and production (Laudal 2010). Consumer reactions to these issues gained impetus in the 1990s due to Nike's poor labor practices prevalent in its overseas apparel manufacturing factories. This fueled many retail apparel brands to explicitly communicate their CSR policies on their websites. With the recent collapse of an apparel manufacturing company in Bangladesh that resulted in loss of more than 1000 lives, retailers like Gap and Walmart faced immense consumer criticism for not signing a labor-backed plan to provide safe working conditions (USA Today, May 21, 2013). Consumers are increasingly holding other retail apparel brands (e.g. Marks and Spencer, Disney, JC Penney, Ralph Lauren, Tommy Hilfiger, Forever 21) accountable for their socially irresponsible business practices concerning environmental and community development issues (Institute of Public and Environmental Affairs 2012).

Given increasing consumer concerns regarding retail apparel brands socially responsible practices, there has been added emphasis on research examining the consumption of (a) apparel manufactured by brands using sweatshop labor (Dickson 2001; Iwanow et al. 2005; Rudell 2006; Shaw et al. 2007); (b) apparel using of organic/recycled materials (Hiller Connell 2011; Hustvedt and Dickson 2009; Kang and Hustvedt 2014a, b); (c) apparel that have fair trade or socially responsible labelling (Hustvedt and Bernard 2010; Hustvedt et al. 2008; Hyllegard et al. 2012) and (d) second-hand/used clothing (Ha-Brookshire and Hodges 2009; Hawley 2006). However, relatively few studies have focused on all dimensions of CSR practices of retail apparel brands and consumers' purchase intentions. For example, Gupta and Hodges's (2012) qualitative study explored Indian consumers' perceptions and expectations of apparel brands' CSR. Furthermore, Kang and Hustvedt (2014a, b) study examining the relationship between consumers' subjective evaluations of CSR efforts and brand equity in the footwear industry, found that brand's perceived CSR transparency and perceived corporate giving directly influenced brand equity. Woo and Jin's (2016) study which employed a US and South Korean students as sample, found a positive relationship between apparel companies CSR dimensions of product responsibility, economic and environmental issues and its brand equity.

Research examining the influence of consumers' values and norms on their willingness to patronize retail apparel brands engaged in CSR practices is scant and has yielded inconsistent and contradictory findings. Specifically, Dickson's (2000) study on personal values and consumer behavior indicated a positive relationship between the importance 
consumers placed on societal values and their suspicion of business intentions encouraging social responsibility. A more recent study by Kim et al. (2012) found that there was a significant effect of social norms and environmental concern on consumers' purchase intentions from retail apparel brands that have environmentally friendly claims in their advertisements. On the other hand, Woo and Jin's (2016) study did not reveal significant relationship between apparel companies CSR dimensions and brand equity based on consumers' cultural values. As CSR is gaining momentum in the apparel industry (Woo and Jin 2016), it is imperative to understand the importance consumers place on retail apparel brands CSR practices based on their values and moral norms, warranting further investigation.

\section{Attitudes and antecedents of attitudes towards a behavior}

According to the TRA, attitudes are influenced by behavioral beliefs, which are beliefs about the likely consequences of a given behavior (Ajzen 1991). Numerous studies have found that beliefs regarding ethical issues in apparel and textiles are important precursors of attitude formation (Dickson 2001; Kozar and Connell 2010; Littrell et al. 1999). These studies have shown that consumer awareness regarding sweatshop labor, ethical codes of conduct, fair trade practices, environmental effects of acquisition, use and disposal of production waste materials and other social issues all play an important role in consumers' apparel purchase decisions. However, minimal research has investigated the role of values and norms on attitude formation. Given changing consumer dynamics (i.e. more ethically aware consumers) it is imperative to understand what factors influence consumption choices. Increasingly, consumers are using non-product attributes, like CSR practices, to evaluate and patronize retail apparel brands. Given the complex nature of apparel consumption decisions, it is important to understand the inherent nature of consumers' value orientations and their influence on the purchase decision process.

\section{Universalistic values and moral norms}

Inherent values guide individuals' choices and behavior. Values are an integral part of individuals' perception of self (Schwartz 1992). Values provide a basis for evaluating alternatives and choices to behave in a certain way and individuals vary in the levels and types of values that are important to them (Ramasamy et al. 2010). Universalistic values represent "understanding, appreciation, tolerance, and protection for the welfare of all people and for nature" (Schwartz 1992, p. 12). A number of studies in other domains have shown that there is a positive relationship between universalistic values and support for environmental and social causes (Nordlund and Garvill 2002; Poortinga et al. 2004; Schultz and Zelezny 1999).

Moral norms are defined as an individual's perception of right or wrong (Ajzen 1991) which takes into account their "personal feelings of...responsibility to perform, or refuse to perform, a certain behavior" (Ajzen 1991, p. 199). Moral norms are based upon one's own value orientation. Universalistic values shape an individual's perspective on social and environmental issues, which in turn governs the activation of their moral norms (Basil and Weber 2006). Universalistic values shape an individual's perspective on social and environmental issues, which in turn governs the activation of their moral norms (Basil and Weber 2006). In the TRA, all normative influences are mediated by subjective 
norms and attitudes (Ajzen and Fishbein 1980; Manstead 2000). Moral norms may take on added salience with respect to how consumers behave in situations involving retail brands' irresponsible behavior in a social or environmental context (Schmeltz 2012). Consumers' moral norms are the basis for the formation of their beliefs and attitudes towards retail apparel brands engaged in CSR activities. Moral norms may, therefore, directly or indirectly affect consumers' decisions to purchase apparel from retail brands engaged in CSR activities. Based on the above discussion, the following relationships are hypothesized:

Hypothesis H1 There is a positive relationship between the importance consumers place on universalistic values and their moral norms.

Hypothesis $\mathrm{H} 2$ There is a positive relationship between consumers moral norms and attitudes towards retail apparel brands engaged in CSR.

Hypothesis H3 There is a positive relationship between consumers moral norms and their intentions to patronize retail apparel brands engaged in CSR.

\section{Benevolent values and subjective norms}

Values greatly influence the formation of attitudes, as well as intentions to behave in a certain way (Ajzen and Fishbein 1980). Understanding a person's value structure provides important insight into what influences their attitudes and intention to support companies involved in CSR. Benevolent values are those pertaining to "preserving and enhancing the welfare of those with whom one is in frequent personal contact" (Schwartz 1992, p. 14). Benevolent values are relevant in consumer ethical decisionmaking since they represent sensitivity to the welfare of others and to actions that put others' interests before one's own. Benevolent values are measured based on the importance individuals attribute to aspects like true friendship, honesty, loyalty to family and friends. Doran (2009) found that benevolent values were salient in US consumers' consumption of fair trade products.

Subjective norms are defined as an individual's perceptions of whether people important to the individual think the behavior should be performed. Subjective norms formed an influencing factor in various consumers' ethical purchasing scenarios (Tarkiainen and Sundqvist 2005). Numerous studies have also lent empirical and conceptual support towards the influence of social referents in clothing consumption behavior (Summers et al. 2006; Ma et al. 2012). Subjective norms in the TRA are a form of social pressure and are known to exert pressure on individuals to act in an environmentally responsible way (Hustvedt and Dickson 2009). Moral norms are conceptually different from subjective norms as they reflect self-expectations and personal responsibility for performing a given behavior (Manstead 2000). The present study posits a theoretical linkage between benevolent values and subjective norms. Consumers who place high importance on benevolence may have a higher probability of being influenced by people who are close to them. Both of these constructs relate to the importance individuals attribute to people 
with whom they are in close contact, and their influence on individual decision making, providing support for the following hypothesis:

Hypothesis $\mathbf{H 4}$ There is a positive relationship between the importance consumers place on benevolent values and their subjective norms.

Randall and Gibson (1991) criticized researchers who tested only relationships hypothesized by TRA and ignored other linkages between subjective norms and attitudes. Numerous studies have found that normative and attitudinal constructs may be dependent and, therefore, subjective norms could influence attitudes toward behavior (Vallerand et al. 1992; Chang 1998). Burke (2006) argued that "norms not only prescribe attitudes and perceptions but also behavior" (p. 124). Attitudes are not formed in isolation and interactions with people may influence an individual through social pressures and behavioral expectations (Kiecolt 1988), thus providing support for the next hypothesis:

Hypothesis $\mathrm{H} 5$ There is a positive relationship between consumers subjective norms and attitudes towards retail apparel brands engaged in CSR.

\section{Consumer patronage intentions}

According to the TRA, the more favorable a person's attitudes and subjective norms are toward a particular behavior, the stronger their intention to perform that behavior (Ajzen 1991). Numerous studies focusing of socially responsible business practices have examined consumers' patronage intentions (Kim et al. 2012; Hustvedt and Dickson 2009; Yan et al. 2010). Hyllegard et al. (2012) found that consumers were more likely to purchase apparel from companies that communicated explicitly about their socially responsible business practices on their hang tags. This study aims to examine the influence of moral norms, subjective norms and attitudes and on consumer patronage intentions. Consumers' have positive image of retail apparel brands engaged in CSR practices. These have ranged from increase in brand equity (Woo and Jin 2016); willingness to pay more (Lee 2011); and purchase intentions (Hyllegard et al. 2012; Yan et al. 2010). This collective body of research provides support for the following hypotheses:

Hypothesis $\mathrm{H} 6$ There is a positive relationship between consumers subjective norms and their intentions to patronize retail apparel brands engaged in CSR.

Hypothesis $\mathbf{H} 7$ There is a positive relationship between consumers attitudes and their intentions to patronize retail apparel brands engaged in CSR.

\section{Methods}

\section{Sampling and data collection}

The sample for this study was recruited using the services of a market research company specializing in consumer panel studies-Survey Sampling International (SSI, n.d.). The online sample was selected from SSI's sampling universe that included proprietary 
panels, as well as partnerships with websites and online sources. Proprietary panel contact methods included an e-mail invitation from SSI. For the internet-based sample, invitations were placed on 1000s of websites to provide maximum diversity of the sampling frame, and respondents were invited to click and "take the survey". Data collection took place in March 2014.

Using an external company for data collection was advantageous, as it ensured a higher number of participants who fit the demographic criteria (US consumers aged 18 and above) required for the present study. The consumer panel thus represented a diverse national sample of US consumers. Demographic profiles represented nearly equivalent distributions in terms of age, gender, income level and educational attainment. According to SSI's data, 467 people entered the survey, with 18 screening out, 42 dropping out in the middle of the survey, and 407 completing the survey, resulting in $87 \%$ completion rate. As the study specified a demographic criteria of US consumers aged 18 or above, the screening question required participants to answer the question regarding their age and residency. If the participants did not fit the demographic criteria they were screened out. The survey was developed and hosted using Survey Gizmo-online survey software. The survey was made available online through a web link for $48 \mathrm{~h}$ as the required sample size for the study was achieved.

\section{Measures}

This study used Dillman's (2000) recommended procedure to develop the on-line survey instrument and included items to assess relationships hypothesized in the research model. The survey consisted of four sections. The first section included items pertaining to self-transcendent values - universalism (nine items) and benevolence (nine items). These items were measured using Schwartz value survey (Schwartz 1992). Respondents were asked to rate the importance of these values on a seven-point Likert-type scale ranging from not at all important (1) to very important (7). The reported reliability for this scale is 0.85 . Sample questions asked participants to rate values based on their importance in their life. Examples of some values in the survey included-equality (equal opportunity for all), social justice (correcting injustice, care for the weak) and protecting the environment (preserving nature).

The second survey section included items that measured moral and subjective norms. Moral norms were measured using items adapted from Dean et al. (2008), whose study assessed both positive and negative moral norms using six items in the context of consumers' choice of organic or conventional food. Only three out of six items that measured positive moral norms were used for this study. The reliability reported for this scale is 0.92 . Respondents were asked to indicate their level of agreement on a seven-point Likert-type scale ranging from strongly disagree (1) to strongly agree (7) with the statement that, "Purchasing apparel from retail brands involved in CSR activities versus not purchasing from retail brands not involved in CSR will make me..." (a) feel like making a personal contribution to something better (b) feel like the morally right thing (c) feel like a better person. Ajzen (1991) indicated that subjective norms are measured as strength of each normative belief multiplied by the person's motivation to comply with the referent in question. A four-item, seven-point semantic differential scale with endpoints "do not influence" and "do influence" was used to report the degree to which 
the respondents believed that other people who were important to them (friends, coworkers, family members and partner) influenced their decision to purchase from retail apparel brands engaged in CSR. To assess motivation to comply, participants were asked corresponding motivation to comply with those referents. Endpoints for the seven-point semantic differential scale were "not at all" to "very much". The reported reliability for this scale is 0.89 .

The third section of the survey included items measuring consumers' attitudes toward patronizing retail apparel brands engaged in CSR activities. Attitudes were assessed by asking respondents to answer a series of seven-point semantic differential questions. A total of four pairs of bipolar adjectives were used to measure the strength of respondents' attitudes towards patronizing apparel retail brands engaged in CSR: (1) bad-good, (2) not contented-contented, (3) not pleased-pleased, and (4) not satisfied-satisfied. These were adapted from $\mathrm{Ma}$ (2007) with a reported reliability coefficient of 0.95 .

The last survey section measured patronage intentions using three subscales-willingness to pay more (one item), recommend (one item), and purchase intentions (three items). Items for purchase intentions and willingness to pay more with respect to retail brands engaged in CSR were adapted from Kim (1995). Items for recommending to family and friends were adapted from Patney (2011). Using different subscales allowed us to measure distinct behavioral manifestations of consumers' patronage intentions. The reliability for subscales ranged from 0.91 to 0.93 . Respondents were asked to indicate their level of agreement on a seven-point Likert-type scale ranging from strongly disagree (1) to strongly agree (7). Demographic characteristics were included at the end of the survey, along with additional questions related to non-profit membership and supporting a cause through apparel purchases.

\section{Factor analysis and reliability check}

Data analysis was conducted using a statistical analysis software package for the social sciences (SPSS version 21.0) to analyze reliability, correlations (see Table 1), and unidimensionality tests. Exploratory factor analysis (EFA) using principal component analysis (PCA) with Varimax rotation was conducted to summarize patterns of correlations among observed variables (Tabachnick and Fidell 2007). An EFA was conducted as items used in this study were adapted from other scales that had been not previously tested in apparel purchasing context. EFA results produced one-factor models, with factor loading $>0.50$ for all items that measured universalism and benevolent values, moral norms, subjective norms, attitudes towards patronizing retail apparel brands engaged in CSR

Table 1 Correlations among research variables $(N=407)$

\begin{tabular}{lllllll}
\hline & UNI & BEN & NORM & SNM & ATT & INTEND \\
\hline Universalistic values (UNI) & 1 & & & & & \\
Benevolent values (BEN) & $0.79^{* *}$ & 1 & & & & \\
Moral norms (NORM) & $0.48^{* *}$ & $0.42^{* *}$ & 1 & & & \\
Subjective norms (SNM) & $0.30^{* *}$ & $0.27^{* *}$ & $0.41^{* *}$ & 1 & & \\
Attitude (ATT) & $0.20^{* *}$ & $0.14^{* *}$ & $0.40^{* *}$ & $0.31^{* *}$ & 1 & - \\
Patronage intentions (INTEND) & $0.38^{* *}$ & $0.28^{* *}$ & $0.54^{* *}$ & $0.47^{* *}$ & $0.47^{* *}$ & 1 \\
\hline
\end{tabular}

** Correlation is significant at the 0.01 level (two-tailed) 
and patronage intentions. Reliability of the constructs was evaluated using Cronbach's $\alpha$ coefficients. The reliability coefficients for all the variables ranged from 0.85 to 0.95 .

\section{Results}

\section{Sample characteristics}

The sample $(\mathrm{N}=407)$ consisted of a slightly higher percentage of female respondents (50.1\%) than male (47.9\%) (percentages may not add up to $100 \%$ due to missing data). The mean age of respondents was 43 with a range of $18-87$ years. Approximately $49 \%$ of the sample held a bachelor's degree or higher. In terms of ethnic background, a majority of the sample was White or European (68.6\%), followed by Black or African American (12.1\%) and Hispanic or Latino (11.1\%); the rest were either Asian American (4.7\%), mixed/biracial $(1.2 \%)$ or other $(1.5 \%)$. In terms of household income levels, approximately half of the sample $(48.7 \%)$ reported their family household income of $<\$ 50,000$. The income level for $21 \%$ of the sample ranged from $\$ 50,000$ to $\$ 74,999$ and the rest (28.4\%) had incomes above $\$ 75,000$. The sample closely mirrors the general population in terms of gender, ethnic and household income distribution (US Census Bureau 2015).

Only $10 \%$ of respondents reported membership in a non-profit organization (NPO) that supported environmental or social causes. However, almost $21 \%$ had supported a cause through their apparel purchases in the past 6 months. Additionally, the results of crosstab analysis conducted between gender and NPO membership revealed that more females $(\mathrm{F}=13 \%, \mathrm{M}=7.4 \%)$ had supported causes through apparel purchases than their male counterparts $(F=23 \%, M=18.8 \%)$. More than $50 \%$ of the respondents who said they had supported a cause through their apparel purchases indicated that their household income was $>$ US\$ 50,000.

\section{Measurement model testing}

Based on exploratory factory analysis results, a measurement model was specified to confirm the factor structure. Confirmatory factor analyses (CFA) (see Table 2) was conducted using the Maximum Likelihood Estimation procedure. Mplus version 7 statistical software was employed for all subsequent statistical analyses (Muthén and Muthén 2000). Prior to conducting the CFA, parceling was conducted on universalistic and benevolent values as both constructs contained a large number of items. Item parceling refers to the averaging of scores for two or more items to obtain item more continuous and normal distributions. Parceling reduces the parameters in a model with a large number of items in order to achieve optimal variable-to-sample-size ratio. This results in more stable parameter estimates (Bagozzi and Heatherton 1994). Additionally, CFA solutions based on parcels have been shown to possess greater power and smaller mean squared errors than individual items (Bandalos 2002). Parceling was deemed appropriate in the present analysis as both the universalistic and benevolent values constructs had large number of items (nine items each). This could have in turn resulted in many parameters needing to be estimated, which would have produced high error terms (Bandalos 2002). To make each parcel more homogeneous, parcels for each variable were developed such that variables with higher factor loadings were combined with those with lower factor loadings (Bagozzi and Heatherton 1994). This process required ranking the 
Table 2 Full confirmatory factor analysis of measurement model $(\mathrm{N}=407)$

\begin{tabular}{|c|c|c|c|c|}
\hline Latent construct/items & $\beta^{* *}$ & $\mathrm{t}$ value & $\mathrm{CR}^{\mathrm{a}}$ & AVE \\
\hline Universalism (UNI) & & & 0.92 & 0.81 \\
\hline Parcel 1: loyal, helpful, true friendship & 0.90 & 69.46 & & \\
\hline Parcel 2: honest, responsible, forgiving & 0.89 & 64.76 & & \\
\hline Parcel 3: a spiritual life, meaning in life, mature love & 0.85 & 49.58 & & \\
\hline Benevolence (BEN) & & & 0.89 & 0.74 \\
\hline Parcel 1: inner harmony, social justice, wisdom & 0.79 & 35.69 & & \\
\hline Parcel 2: equality, a world at peace, broad-minded & 0.88 & 58.26 & & \\
\hline $\begin{array}{l}\text { Parcel 3: Unity with nature, Protecting the environment, a world } \\
\text { of beauty }\end{array}$ & 0.90 & 64.06 & & \\
\hline Moral norms (MNORM) & & & 0.90 & 0.75 \\
\hline \multicolumn{5}{|l|}{$\begin{array}{l}\text { Purchasing apparel from retail brands involved in CSR activities } \\
\text { versus not purchasing from retail brands not involved in CSR } \\
\text { will make me }\end{array}$} \\
\hline ...feel like making a personal contribution to something better & 0.89 & 60.62 & & \\
\hline ...feel like the morally right thing & 0.89 & 58.44 & & \\
\hline ...feel like a better person & 0.82 & 41.58 & & \\
\hline Subjective norms ${ }^{\mathrm{b}}$ (SNORM) & & & 0.93 & 0.75 \\
\hline $\begin{array}{l}\text { My friends influence my decision to purchase from apparel retail } \\
\text { brands engaged in CSR }\end{array}$ & 0.75 & 31.76 & & \\
\hline $\begin{array}{l}\text { My co-workers influence my decision to purchase from apparel } \\
\text { retail brands engaged in CSR }\end{array}$ & 0.89 & 66.10 & & \\
\hline $\begin{array}{l}\text { My family members influence my decision to purchase from } \\
\text { apparel retail brands engaged in CSR }\end{array}$ & 0.92 & 87.43 & & \\
\hline $\begin{array}{l}\text { My partner influences my decision to purchase from apparel } \\
\text { retail brands engaged in CSR }\end{array}$ & 0.91 & 77.68 & & \\
\hline Attitudes towards patronizing retail brands engaged in CSR (ATT) & & & 0.93 & 0.75 \\
\hline \multicolumn{5}{|l|}{$\begin{array}{l}\text { Buying apparel from retail brands involved in CSR activities versus } \\
\text { not buying from retail brands not involved in CSR would make } \\
\text { me feel }\end{array}$} \\
\hline Good-bad & 0.75 & 31.76 & & \\
\hline Contented-not contented & 0.89 & 66.10 & & \\
\hline Pleased-not pleased & 0.92 & 87.43 & & \\
\hline Satisfied-not satisfied & 0.91 & 77.68 & & \\
\hline Patronage intentions (INTEND) & & & 0.93 & 0.69 \\
\hline $\begin{array}{l}\text { I intend to pay more to apparel retail brands involved in CSR } \\
\text { activities }\end{array}$ & 0.84 & 52.24 & & \\
\hline $\begin{array}{l}\text { I intend to recommend apparel retail brands engaged in CSR } \\
\text { activities to my friends, family members and co-workers }\end{array}$ & 0.77 & 35.63 & & \\
\hline $\begin{array}{l}\text { The likelihood that I would purchase from apparel retail brands } \\
\text { engaged in CSR is very high }\end{array}$ & 0.88 & 65.74 & & \\
\hline $\begin{array}{l}\text { I am likely to purchase from apparel retail brands engaged in CSR } \\
\text { in the future }\end{array}$ & 0.91 & 85.88 & & \\
\hline $\begin{array}{l}\text { I have every intention to purchase from apparel retail brands } \\
\text { engaged in CSR }\end{array}$ & 0.90 & 79.85 & & \\
\hline$* * p \leq 0.001$ & & & & \\
\hline e $r$ & & & & \\
\hline
\end{tabular}

factor loading scores for each item by construct in ascending order and evenly distributing them into the created parcels. See Table 2 for items in each resulting parcel. 
Results of the CFA for the full measurement model $\left(\mathrm{X}^{2}=450.725 \mathrm{df}=192\right.$ at $\mathrm{p}$ value $<0.001$, CFI $=0.97$, TLI $=0.96$, RMSEA $=0.06$, SRMR $=0.04)$, indicated that the model fit the data well. Convergent and discriminant validity of the measures was assessed. All factor loadings of the indicators were significant and exceeded 0.7 confirming convergent validity of the measures. Also, the composite reliability and average variance extracted (AVE) of the constructs were above the acceptable threshold levels of 0.7 and 0.5 respectively (Nunnally 1978). Discriminant validity was confirmed as the AVE for one construct was greater than the squared correlation between that construct and other constructs in the model (Anderson and Gerbing 1988). In addition, $t$ values and $R^{2}$ were also referenced to assess the strength of each item identified for each construct (Cronbach and Meehl 1955). Full CFA results are shown in Table 2.

\section{Structural model and hypothesis testing}

After identifying a well-fitting measurement model, the hypothesized structural model was tested using structural equation modeling. Structural model and hypotheses testing was conducted using path analysis. A structural model with six latent variables was tested to examine the hypothesized relationships described in H1-H7. Structural model analysis showed squared multiple correlations $\left(R^{2}\right)$ for endogenous variables ranging from 0.11 to 0.41 , and revealed that the hypothesized paths were as predicted with beta weights statistically significant at $\mathrm{p}<0.01$ (see Table 3 ). The fit indices $\left(\mathrm{X}^{2}=502.043\right.$, $\mathrm{df}=199$ at $\mathrm{p}$ value $<0.001, \mathrm{CFI}=0.97, \mathrm{TLI}=0.96$, $\mathrm{RMSEA}=0.06$, SRMR $=0.06)$ of the hypothesized model revealed a good fit to the data (Hair et al. 2010).

The results of hypothesis testing (see Fig. 2) were in line with relationships posited between universalistic values and moral norms. A positive, significant relationship $(\beta=0.52, \mathrm{p}<0.001$ ) was found (see Table 3), providing support for hypothesis H1. Universalistic values explained $27 \%$ of the total variance of moral norms. Moral norms positively influenced consumers' attitudes towards retail apparel brands engaged in CSR ( $\beta=0.35, \mathrm{p}<0.001)$. Thus, hypothesis $\mathrm{H} 2$ was supported. Furthermore, a positive and significant relationship $(\beta=0.38, \mathrm{p}<0.001)$ was found between moral norms and consumers' patronage intentions towards retail apparel brands engaged in CSR activities, supporting H3. The findings of this study also indicated that consumers who attribute

Table 3 Standardized path coefficients of hypothesized model with $\mathbf{t}$ ratios for the structural model $(\mathrm{N}=407)$

\begin{tabular}{lllll}
\hline Predictor variables & \multicolumn{2}{l}{ Outcome variables } & \\
\cline { 2 - 5 } & Moral norms & Subjective norms & Attitude & Patronage intention \\
\hline Universalism values & $0.52^{* *}(12.74)^{\mathrm{a}}$ & - & - & - \\
Benevolent values & - & $0.33^{* *}(6.81)$ & - & \\
Moral norms & - & - & $0.35^{* *}(6.70)$ & $0.38^{* *}(7.82)$ \\
Subjective norms & - & - & $0.19^{* *}(3.65)$ & $0.27^{* *}(5.74)$ \\
Attitude & - & - & - & $0.28^{* *}(5.10)$ \\
$R^{2}$ & 0.27 & 0.11 & 0.18 & 0.41
\end{tabular}

Model fit indices: Chi square $\left(x^{2}\right)=502.043, d f=199$ at $p$ value $<0.001, C F I=0.97, T L I=0.96, R M S E A=0.06, S R M R=0.06$ $R^{2}$-percentage of variance explained due to independent variable

** $\mathrm{p} \leq 0.001$

a $\mathrm{t}$ ratios are in parentheses 


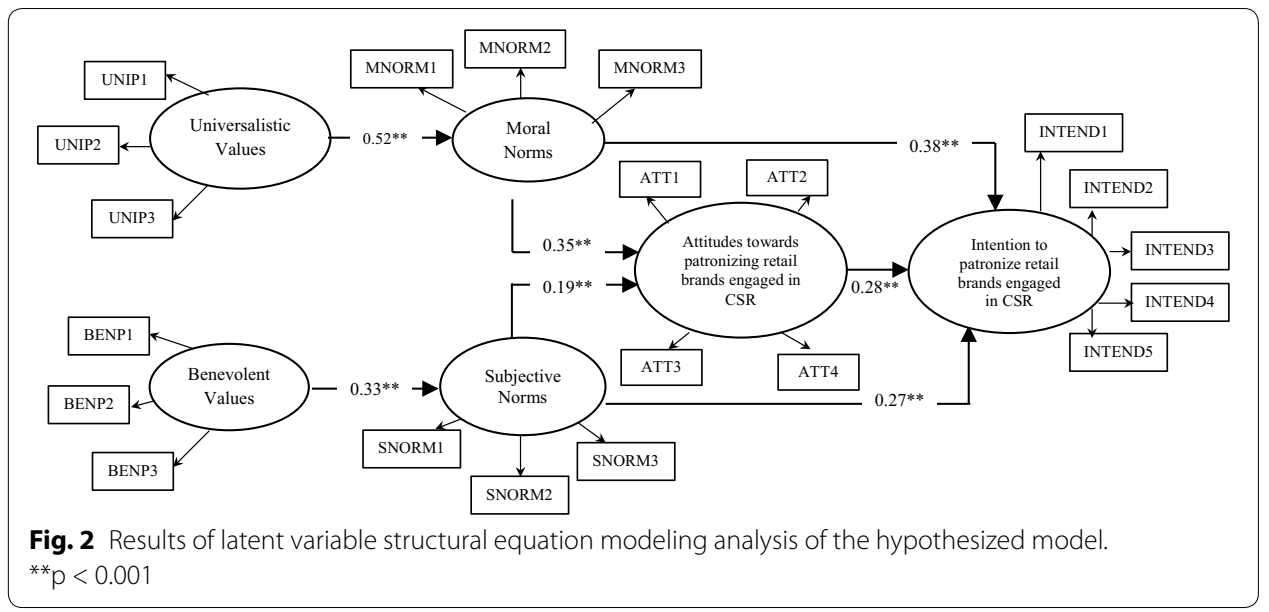

high importance to benevolent values were also highly influenced by significant others $(\beta=0.33, p<0.001)$, supporting hypothesis $H 4$. The results of this study also confirm the positive relationship between subjective norms and attitudes $(\beta=0.19, \mathrm{p}<0.001)$ providing support for hypothesis $\mathrm{H} 5$. There was a positive and significant relationship between patronage intentions and (a) subjective norms $(\beta=0.27, \mathrm{p}<0.001)$; and (b) attitudes $(\beta=0.28, \mathrm{p}<0.001)$, providing support for hypotheses $\mathrm{H} 6$ and $\mathrm{H} 7$.

\section{Discussion}

Recent research has explored CSR and consumer behavior in the retail apparel context (Bhaduri and Ha-Brookshire 2011; Kang and Hustvedt 2014b; Woo and Jin 2016). However, the scope of these studies primarily focused on consumers perceived trust, perceived transparency and its influence on brand equity. Woo and Jin (2016) also explored the role of cultural values on brand equity, but did not find any significant relationship. Antecedents of how consumers develop brand trust or evaluate company's social responsibility may be logically linked to their value structures and norms. Research pertaining specifically to values and norms in the CSR and retail apparel context is limited (Dickson 2000; Kim et al. 2012). Against this background, the present study explored the motives and values guiding consumers' intentions to patronize retail apparel brands engaged in CSR.

Findings of this study provide strong empirical support regarding the importance of universalistic and benevolent values in activation of moral and subjective norms. Results are also consistent with prior studies concerning the role of significant others in ethical context related consumers' attitudes towards social responsible labelling and marketing (Kim et al. 2012; Hyllegard et al. 2012). There is some evidence linking employees' individual values, pro-social behavior and CSR in organizational context. Findings from this study support the linkage of Schwartz's self transcendent values and norms to attitude formation and patronage intentions of retail apparel brands engaged in CSR activities. These findings are consistent with previous studies conducted in an organizational context in other domains (Basil and Weber 2006; Ramasamy et al. 2010).

Both moral and subjective norms were found to exert influence in the formation of positive attitudes and intentions to patronize retail apparel brands engaged in CSR 
activities. Specifically, moral norms have a more $(\beta=0.35, \mathrm{p}<0.001)$ powerful effect on attitude formation than subjective norms $(\beta=0.19, \mathrm{p}<0.001)$. The findings confirm previous work (Dean et al. 2008) regarding central role of moral norms in consumers' ethical decision making process. Taken together, individual factors (values and moral norms) and significant others exert substantial influence over consumers' ethical decision making processes. Findings from this study also suggest that consumers are increasingly expressing ethical values through their purchasing decisions (Golob et al. 2008).

In conclusion, this study provides empirical evidence that illuminates the largely unexplored relationship between values, norms, attitudes and patronage intentions. Specifically, this study indicated the magnitude of importance of personal values (universalistic and benevolent values) $\left(R^{2}=0.38\right)$, in consumers' development of moral and social norms. The results of this study provide timely and highly relevant information regarding the role of individuals' moral perspective in purchase decision process. Moral norms, subjective norms, and attitudes collectively explained $41 \%$ of the total variance of consumers' intentions to patronize retail apparel brands engaged in CSR activities. Furthermore, the findings of this study contribute immensely to the literature and provide understanding of the role of consumers' moral norms on development of positive attitudes and intentions to patronize retail apparel brands engaged in CSR practices. Specifically, the relationship between moral norms and attitudes $(\beta=0.35, \mathrm{p}<0.001)$ was stronger than subjective norms and consumers' attitudes $(\beta=0.19, \mathrm{p}<0.001)$. Further, moral norms exerted the most influence on consumers' intentions to patronize $(\beta=0.38$, $\mathrm{p}<0.001)$ retail apparel brands engaged in CSR activities when compared to subjective norms $(\beta=0.27, \mathrm{p}<0.001)$ and attitudes $(\beta=0.28, \mathrm{p}<0.001)$. This study explored the central role of consumers' moral norms filling a gap in the sustainable apparel consumption literature. Apparel consumption decisions are largely based on utility considerations in the minds of consumers (Irani and Hanzaee 2011). However, findings of this study indicate that individuals also operate according to their deontological principles (Ferrell and Ferrell 2011) largely based on their values and moral norms.

\section{Conclusion}

Social responsibility is a much broader concept in the retail apparel industry. Understanding consumers' decision making processes concerning CSR provides direction to marketing managers and advances the research pertaining to marketing and consumer ethics. Individual ethical reasoning processes and organizations' ethical climate impact decision making process for both consumers and brands alike. Findings of the present study bridge theory and practice by providing enhanced understanding of how consumers' employ universalistic and benevolent values in retail apparel purchases. We specifically examined how consumers' personal moral perspectives influence their attitudes towards retail apparel brands engaged in CSR. Results indicate that the consumers in this study clearly value retail apparel brands' CSR and use this information when considering apparel purchases. The findings show that CSR has dual managerial implications for retail apparel brands, serving as both a viable organizational activity that creates goodwill and positive brand associations, and as a business strategy that may have positive performance outcomes for retail apparel firms. 
This study is among the very few to date that have examined CSR in the apparel retailing context. As such, it contributes to theory development regarding the ethical decision making process of consumers. The findings of this study provides important theoretical implications by addressing research gaps in two ways. First, few studies have examined consumer behavior in retail apparel CSR context. This study specifically, developed and empirically tested an integrative descriptive model incorporating elements of TRA, moral norms, and Schwartz's value theory (1992). The relationships outlined in this model address the recommendations of Conner and Armitage (1998) to include the measures of values and moral norm in behavioral theories. From a theoretical perspective, this study contributes to theory development by integrating elements of Schwartz Value Theory (universalistic values, and benevolent values) in the TRA framework providing more explanatory power to this behavioral theory. This study also proposed new linkages that provide a unique perspective on consumers' ethical decision making and provided analysis of antecedents concerning why and how consumers' moral and subjective norms are activated in the consumer decision processes. These norms in turn influence consumers' attitudes and patronage intentions towards retail apparel brands engaged in CSR activities. The findings of this study provide impetus for further theory testing in this largely unexplored area. We propose numerous future research directions that contribute towards a richer understanding of the underlying dynamics among CSR, consumer expectations of ethical behavior, and intentions to patronize retail apparel brands engaged in CSR.

Several important marketing implications emerged from this study for retail apparel brands engaged in CSR or planning to engage in CSR in the future. First, this study showed that values and norms are integral in consumer ethical decision making process. To target more ethically aware consumers, companies should adequately incorporate their CSR activities in their marketing communications. Secondly, consumer segmentation and understanding the attitudes of consumers are important in formulating marketing strategies for retail apparel brands. Findings of this study propose that brands would benefit from investing in identifying the right target market segments who place high importance their self transcendent values and moral norms and create targeted marketing strategies. By engaging in CSR activities and effectively promoting retail apparel brands' socially responsible image, brands can leverage the social value created. These actions would directly benefit the financial bottom-line of the brand along with increasing the firm's brand equity. The provision of information regarding retail apparel brands' socially responsible business practices may also positively influence consumers' patronage intentions. Thus, findings of the present study demonstrate that if retail apparel brands effectively promote information regarding their responsible practices, consumers may be more likely to take them into account during their purchase decisions.

This study has several limitations that should be noted. As the survey was administered online using the services of a marketing research company, the sample was limited to consumers who had access to the internet. This may limit the generalization of findings. Another limitation is that this study only measured the intention to patronize retail apparel brands engaged in CSR activities. Actual patronage behavior could not be investigated, limiting the findings of this study. However, it can be argued that behavioral intention and actual behavior are strongly correlated (Vermier and Verbeke 2006). 
This study demonstrates that consumers' values and norms play a significant role in their attitude and patronage intentions. The findings of this study are unique as the proposed theoretical model addressed both individual (moral) norms and social (subjective) norms. Future research could investigate other variables (e.g. consumer awareness of CSR issues in the retail apparel industry, concern regarding environment and social equality, past behavior of supporting socially responsible brands) that may influence consumers' intentions to patronize retail apparel brands engaged in CSR activities. This study introduced personal values and norms into one specific behavioral theory, the TRA. To further test and validate the findings of this theory, other variables within Theory of Planned Behavior could be introduced in an ethical decision making context.

To further validate the results of this study, scenario-based experimental research could also be designed. Scenarios encompassing environmental and social issues could be developed and participants randomly assigned to determine whether the relationship between values, attitudes and intentions still holds good. This study provides important insights into the nature of values and expectations in the TRA framework and consumers ethical decision making context. A study based on a larger sample would provide more support and also confirm the stability of these important findings within an existing model of ethical consumer decision making. As this is the first study of its kind to address the apparel purchasing behavior of US consumers, it is recommended that this study be replicated with consumers in other geographical areas and cultural settings.

This research is an important first step towards understanding consumer ethical decision making and how it interacts with CSR strategies on the part of apparel retail brands. Subsequent studies can further analyze the importance of retail apparel brands CSR practices based on different aspects of consumer demographics such as age, gender, income levels and education.

\section{Authors' contributions}

SD developed the literature review and theoretical framework, collected data for the research study, and drafted the manuscript. LSN guided the development of the hypotheses, theoretical framework, and reporting of the results. All authors read and approved the final manuscript.

\section{Author details}

1 Department of Design and Merchandising, College of Health and Human Sciences, Colorado State University, Fort Collins, CO 80523, USA. ${ }^{2}$ Department of Apparel, Events, and Hospitality Management, College of Human Sciences, lowa State University, Ames, IA 50011-1121, USA.

\section{Competing interests}

The authors declare that they have no competing interests.

Received: 31 December 2015 Accepted: 17 October 2016

Published online: 28 February 2017

\footnotetext{
References

Ajzen, I. (1991). The theory of planned behavior. Organizational Behavior and Human Decision Processes, 50(2), 179-211. Ajzen, I., \& Fishbein, M. (1980). Understanding attitudes and predicting social behavior. Englewood Cliffs, NJ: Prentice Hall. Anderson, J. C., \& Gerbing, D. W. (1988). Structural equation modeling in practice: A review and recommended two-step approach. Psychological Bulletin, 103(3), 411.

Arvola, A., Vassallo, M., Dean, M., Lampila, P., Saba, A., Lähteenmäki, L., et al. (2008). Predicting intentions to purchase organic food: The role of affective and moral attitudes in the theory of planned behaviour. Appetite, 50(2), 443-454.

Bagozzi, R. P., \& Heatherton, T. F. (1994). A general approach to representing multifaceted personality constructs: Application to state self-esteem. Structural Equation Modelling, 1, 35-67.

Bandalos, D. L. (2002). The effects of item parceling in goodness-of-fit and parameter estimate bias in structural equation modeling. Structural Equation Modelling, 9(1), 78-102.

Basil, D., \& Weber, D. (2006). Values motivation and concern for appearances: The effect of personality traits on responses to corporate social responsibility. International Journal of Nonprofit and Voluntary Sector Marketing, 11(1), 31-72.
} 
Bhaduri, G., \& Ha-Brookshire, J. E. (2011). Do transparent business practices pay? Exploration of transparency and consumer purchase intention. Clothing and Textiles Research Journal, 29(2), 135-149.

Brosdahl, D. J., \& Carpenter, J. M. (2010). Consumer knowledge of the environmental impacts of textile and apparel production, concern for the environment, and environmentally friendly consumption behavior. Journal of Textile and Apparel, Technology and Management, 6(4), 1-9.

Brown, T. J., \& Dacin, P. A. (1997). The company and the product: Corporate associations and consumer product responses. The Journal of Marketing, 61(1), 68-84.

Burke, P. J. (2006). Contemporary social psychological theories. Stanford, CA: Stanford Social Sciences.

Chan, T. Y., \& Wong, C. W. (2012). The consumption side of sustainable fashion supply chain: understanding fashion consumer eco-fashion consumption decision. Journal of Fashion Marketing and Management: An International Journal, 16(2), 193-215.

Chang, M. K. (1998). Predicting unethical behavior: A comparison of the theory of reasoned action and the theory of planned behavior. Journal of Business Ethics, 17(16), 1825-1834.

Cone Inc. (2013). Global CSR report. http://www.conecomm.com/2013-global-csr-study-release.

Conner, M., \& Armitage, C. J. (1998). Extending the theory of planned behavior: A review and avenues for further research. Journal of Applied Social Psychology, 28(15), 1429-1464.

Cronbach, L. J., \& Meehl, P. E. (1955). Construct validity in psychological tests. Psychological Bulletin, 52, 281-302.

Dargusch, P., \& Ward, A. (2010). Understanding corporate social responsibility with the integration of supply chain management in outdoor apparel manufacturers in North America and Australia. International Journal of Business and Management Science, 3(1), 93.

de Abreu, M. C. S., de Castro, F., de Assis Soares, F., \& da Silva Filho, J. C. L. (2012). A comparative understanding of corporate social responsibility of textile firms in Brazil and China. Journal of Cleaner Production, 20(1), 119-126.

Dean, M., Raats, M. M., \& Shepherd, R. (2008). Moral concerns and consumer choice of fresh and processed organic foods. Journal of Applied Social Psychology, 38(8), 2088-2107.

Dickson, M. A. (2000). Personal values, beliefs, knowledge, and attitudes relating to intentions to purchase apparel from socially responsible businesses. Clothing and Textiles Research Journal, 18(1), 19-30.

Dickson, M. A. (2001). Utility of no sweat labels for apparel consumers: Profiling label users and predicting their purchases. Journal of Consumer Affairs, 35(1), 96-119.

Dickson, M., \& Eckman, M. (2006). Social responsibility: The concept as defined by apparel and textile scholars. Clothing and Textiles Research Journal, 24(4), 178-191.

Dillman, D. A. (2000). Mail and internet surveys: The tailored design method. New York, NY: Wiley.

Dodd, M. D., \& Supa, D. W. (2011). Understanding the effect of corporate social responsibility on consumer purchase intention. Public Relations Journal, 5(3), 1-19.

Doran, C. J. (2009). The role of personal values in fair trade consumption. Journal of Business Ethics, 84(4), 549-563.

Ferrell, O. C., Crittenden, V. L., Ferrell, L., \& Crittenden, W. F. (2013). Theoretical development in ethical marketing decision making. AMS Review, 3(2), 51-60.

Ferrell, O. C., \& Ferrell, L. (2011). The responsibility and accountability of CEOs: The last interview with Ken Lay. Journal of Business Ethics, 100(2), 209-219.

Godin, G., Conner, M., \& Sheeran, P. (2005). Bridging the intention-behaviour gap: The role of moral norm. British Journal of Social Psychology, 44(4), 497-512.

Golob, U., Lah, M., \& Jančič, Z. (2008). Value orientations and consumer expectations of corporate social responsibility. Journal of Marketing Communications, 14(2), 83-96.

Groza, M. D., Pronschinske, M. R., \& Walker, M. (2011). Perceived organizational motives and consumer responses to proactive and reactive CSR. Journal of Business Ethics, 102(4), 639-652.

Gupta, M., \& Hodges, N. (2012). Corporate social responsibility in the apparel industry: An exploration of Indian consumers' perceptions and expectations. Journal of Fashion Marketing and Management, 16(2), 216-233.

Ha-Brookshire, J. E., \& Hodges, N. N. (2009). Socially responsible consumer behavior? Exploring used clothing donation behavior. Clothing and Textiles Research Journal, 27(3), 179-196.

Hair, J. F., Black, B., Babin, B., \& Anderson, R. E. (2010). Multivariate data analysis. Upper Saddle River, NJ: Pearson Prentice Hall.

Hawley, J. M. (2006). Digging for diamonds: A conceptual framework for understanding reclaimed textile products. Clothing and Textiles Research Journal, 24(3), 262-275.

Hiller Connell, K. Y. (2011). Exploring consumers' perceptions of eco-conscious apparel acquisition behaviors. Social Responsibility Journal, 7(1), 61-73.

Hunt, S. D., \& Vitell, S. (1986). A general theory of marketing ethics. Journal of Macromarketing, 6(1), 5-16.

Hustvedt, G., \& Bernard, J. C. (2010). Effects of social responsibility labelling and brand on willingness to pay for apparel. International Journal of Consumer Studies, 34(6), 619-626.

Hustvedt, G., \& Dickson, M. A. (2009). Consumer likelihood of purchasing organic cotton apparel: Influence of attitudes and self-identity. Journal of Fashion Marketing and Management, 13(1), 49-65.

Hustvedt, G., Peterson, H. H., \& Chen, Y. J. (2008). Labelling wool products for animal welfare and environmental impact. International Journal of Consumer Studies, 32(5), 427-437.

Hyllegard, K., Yan, R. N., Ogle, J. P., \& Lee, K. H. (2012). Socially responsible labeling: The impact of hang tags on consumers' attitudes and patronage intentions toward an apparel brand. Clothing and Textile Research Journal, 31(1), 51-66.

Institute of Public and Environmental Affairs. (2012). Sustainable apparel's critical blind spot. http://www.ipe.org.cn/ Upload/Report-Textiles-Phase-II-EN.pdf.

Irani, N., \& Hanzaee, K. H. (2011). The effects of variety-seeking buying tendency and price sensitivity on utilitarian and hedonic value in apparel shopping satisfaction. International Journal of Marketing Studies, 3(3), 89-104.

Iwanow, H., McEachern, M. G., \& Jeffrey, A. (2005). The influence of ethical trading policies on consumer apparel purchase decisions: A focus on The Gap Inc. International Journal of Retail \& Distribution Management, 33(5), 371-387.

Kang, J., \& Hustvedt, G. (2014a). Building trust between consumers and corporations: The role of consumer perceptions of transparency and social responsibility. Journal of Business Ethics, 125(2), 253-265. 
Kang, J., \& Hustvedt, G. (2014b). The contribution of perceived labor transparency and perceived corporate giving to brand equity in the footwear industry. Clothing and Textiles Research Journal, 32(4), 296-311.

Kiecolt, K. J. (1988). Recent developments in attitudes and social structure. Annual Review of Sociology, 14(1), 381-403.

$\mathrm{Kim}, \mathrm{H}$. S. (1995). Consumer response toward apparel products in advertisements containing environmental claims (Doctoral dissertation). Retrieved from UMI (9531755).

Kim, H., Lee, E.-J., \& Hur, W.-M. (2012). The normative social influence on eco-friendly consumer behaviour: The moderating effect of environmental claims. Clothing and Textiles Research Journal, 30(1), 4-18.

Knut, H., Reeves, M., Strengvelken, I. V., Audretsch, M., Kiron, D., \& Kruschwitz, N. (2012). Sustainability nears a tipping point. MIT Sloan Management Review, 53(2), 69-74.

Kozar, J. M., \& Connell, K. (2010). Socially responsible knowledge and behaviors: Comparing upper-vs. lower-classmen. College Student Journal, 44(2), 279-293.

Kozar, J. M., \& Connell, K. Y. H. (2013). Socially and environmentally responsible apparel consumption: Knowledge, attitudes, and behaviors. Social Responsibility Journal, 9(2), 315-324.

Kozar, J. M., \& Marcketti, S. B. (2011). Examining ethics and materialism with purchase of counterfeits. Social Responsibility Journal, 7(3), 393-404.

KPMG. (2015). Survey of corporate sustainability reporting. https://www.kpmg.com/CN/en/lssuesAndlnsights/ArticlesPublications/Documents/kpmg-survey-of-corporate-responsibility-reporting-2015-O-201511.pdf.

Laudal, T. (2010). An attempt to determine the CSR potential of the international clothing business. Journal of Business Ethics, 96(1), 63-77.

Lee, S. (2011). Consumers'value, environmental consciousness, and willingness to pay more toward green-apparel products. Journal of Global Fashion Marketing, 2(3), 161-169.

Lee, K. H., \& Shin, D. (2010). Consumers' responses to CSR activities: The linkage between increased awareness and purchase intention. Public Relations Review, 36(2), 193-195.

Lii, Y. S., \& Lee, M. (2012). Doing right leads to doing well: When the type of CSR and reputation interact to affect consumer evaluations of the firm. Journal of Business Ethics, 105(1), 69-81.

Littrell, M. A., Ogle, J. L. P., \& Kim, S. (1999). Marketing ethnic apparel: Single or multiple consumer segments? Journal of Fashion Marketing and Management, 3(1), 31-43.

Ma, Y. J. (2007). Young consumers' fair trade consumption: Application of the theory of planned behavior to non-food fair trade purchases (Doctoral dissertation). Retrieved from UMI (3274860).

Ma, Y. J., Littrell, M. A., \& Niehm, L. (2012). Young female consumers'intentions toward fair trade consumption. International Journal of Retail \& Distribution Management, 40(1), 41-63.

Manstead, A. S. R. (2000). The role of moral norm in the attitude-behavior relation. In D. J. Terry \& M. A. Hogg (Eds.), Attitudes, behavior, and social context: The role of norms and group membership: Applied social research (pp. 11-30). Mahwah, NJ: Lawrence Erlbaum.

Marin, L., Ruiz, S., \& Rubio, A. (2009). The role of identity salience in the effects of corporate social responsibility on consumer behavior. Journal of Business Ethics, 84(1), 65-78.

Moosmayer, D. C., \& Fuljahn, A. (2010). Consumer perceptions of cause related marketing campaigns. Journal of Consumer Marketing, 27(6), 543-549.

Muthén, L. K., \& Muthén, B. O. (2000). Mplus user's guide. Los Angeles, CA: Muthen \& Muthen.

Nordlund, A. M., \& Garvill, J. (2002). Value structures behind proenvironmental behavior. Environment and Behavior, 34(6), $740-756$.

Nunnally, J. C. (1978). Psychometric theory (2nd ed.). New York: McGraw Hill.

O'Donnell, J. (2013). Survey: Most would boycott irresponsible company. USA Today. http://www.usatoday.com/story/ money/business/2013/05/21/consumers-boycott-companies-bad-behavior-gap-protests/2343619/.

Patney, M. (2011). Indian consumers and their mall patronage: Application of cultural-self and the theory of planned behavior to patronage intentions (Doctoral dissertation). Retrieved from UMI (3439067).

Peterson, H. H., Hustvedt, G. M., \& Chen, Y. J. K. (2012). Consumer preferences for sustainable wool products in the United States. Clothing and Textiles Research Journal, 30(1), 35-50.

Phau, I., \& Ong, D. (2007). An investigation of the effects of environmental claims in promotional messages for clothing brands. Marketing Intelligence \& Planning, 25(7), 772-788.

Poortinga, W., Steg, L., \& Vlek, C. (2004). Values, environmental concern, and environmental behavior: A study into household energy use. Environment and Behavior, 36(1), 70-93.

Ramasamy, B., Yeung, M. C., \& Au, A. K. (2010). Consumer support for corporate social responsibility (CSR): The role of religion and values. Journal of Business Ethics, 91(1), 61-72.

Randall, D. M., \& Gibson, A. M. (1991). Ethical decision making in the medical profession: An application of the theory planned behavior. Journal of Business Ethics, 10(2), 111-122.

Rest, J. (1983). Morality. In J. Flavell \& E. Markman (Eds.), Handbook of child psychology (pp. 556-629). New York, NY: Wiley,

Rudell, F. (2006). Shopping with a social conscience: Consumer attitudes toward sweatshop labor. Clothing and Textiles Research Journal, 24(4), 282-296.

Schmeltz, L. (2012). Consumer-oriented CSR communication: Focusing on ability or morality? Corporate Communications: An International Journal, 17(1), 29-49.

Schultz, P., \& Zelezny, L. (1999). Values as predictors of environmental attitudes: Evidence for consistency across 14 countries. Journal of Environmental Psychology, 19(3), 255-265.

Schwartz, S. H. (1992). Universals in the content and structure of values: Theoretical advances and empirical tests in 20 countries. Advances in Experimental Social Psychology, 25(1), 1-65.

Shaw, D., Shiu, E. M. K., Bekin, C., Hassan, L., \& Hogg, G. (2007). Intending to be ethical: An examination of consumer choice in sweatshop avoidance. Advances in Consumer Research, 34, 31-38.

Simmons, C. J., \& Becker-Olsen, K. L. (2006). Achieving marketing objectives through social sponsorships. Journal of Marketing, 70(4), 154-169.

Summers, T. A., Belleau, B. D., \& Xu, Y. (2006). Predicting purchase intention of a controversial luxury apparel product. Journal of Fashion Marketing and Management, 10(4), 405-419. 
Tabachnick, B., \& Fidell, L. (2007). Using multivariate analyses (5th ed.). New York, NY: Harper and Row.

Tarkiainen, A., \& Sundqvist, S. (2005). Subjective norms, attitudes and intentions of Finnish consumers in buying organic food. British Food Journal, 107(11), 808-822.

US Census Bureau. (2015). Quickfacts. http://www.census.gov/quickfacts/table.

Vallerand, R. J., Deshaies, J., Cuerrier, L. G., \& Mongeau, C. (1992). Ajzen and Fishbein's theory of reasoned action as applied to moral behavior: A confirmatory analysis. Journal of Personality and Social Psychology, 62, 98-109.

Vermeir, l., \& Verbeke, W. (2008). Sustainable food consumption among young adults in Belgium: theory of planned behaviour and the role of confidence and values. Ecological Economics, 64(3), 542-553.

Woo, H., \& Jin, B. (2016). Culture doesn't matter? The impact of apparel companies' corporate social responsibility practices on brand equity. Clothing and Textiles Research Journal, 34(1), 20-36.

Yan, R. N., Hyllegard, K. H., \& Blaesi, L. F. (2010). Marketing eco-fashion: The influence of brand name and message explicitness. Journal of Marketing Communications, 18(2), 151-168.

\section{Submit your manuscript to a SpringerOpen ${ }^{\circ}$ journal and benefit from:}

- Convenient online submission

\section{- Rigorous peer review}

- Immediate publication on acceptance

- Open access: articles freely available online

- High visibility within the field

- Retaining the copyright to your article

Submit your next manuscript at $\gg$ springeropen.com 